\title{
DO DEATH TAXES DESERVE TO DIE? AN INTERNATIONAL SEARCH FOR ALTERNATIVES
}

\author{
Palesa Makoti* \\ University of Pretoria \\ palesakatleho.makoti@angloamerican.com
}

Received: September 2013

\author{
Rudi Oosthuizen" \\ University of Pretoria \\ rudi.oosthuizen@up.ac.za
}

Accepted: August 2014

\begin{abstract}
The death tax debate has been going on for a long time, with opponents and proponents of death taxes citing various reasons for retaining, amending or abolishing the taxes and no obvious answer coming to the fore. This study conducted a search for alternative taxes that could replace death taxes. The search transcended national borders in order to identify possible solutions to this ageold problem. The suitability of the alternatives (in the eyes of both the opponents and proponents of death taxes) was measured by comparing the advantages and disadvantages associated with each alternative identified to the advantages and disadvantages associated with death taxes. This study further evaluated whether any of the identified alternatives would be suitable for South Africa. It summarises the available alternatives, their advantages and disadvantages. It also concludes that extensive further research is required to arrive at an optimal solution for South Africa.
\end{abstract}

Keywords

Advantages, alternatives, death taxes, disadvantages, estate tax, inheritance tax, opponents, proponents.

*Ms P Makoti is a master's student in the Department of Taxation, University of Pretoria, South Africa.

\# Mr R Oosthuizen is a senior lecturer in the Department of Taxation, University of Pretoria, South Africa. 


\section{INTRODUCTION}

The opponents of death taxes stand in the left corner of the ring and the proponents in the right corner. When the bell rings, these two opposing sides exchange blows over death taxes. The death tax debate lingers in the background of all social conversations and flares up at critical times, such as in election years. The only way in which this debate will end is if an alternative to death taxes is found - an alternative that is suitable in the eyes of both the opponents and proponents of death taxes.

A government may choose to make use of any number of different taxes to fund the expenditure it needs to incur and also to achieve its micro- and macro-economic objectives. Taxes should always be a reflection of the prevailing social and economic times (Organisation for Economic Co-operation and Development (OECD), not dated).

The contemporary form of death taxes took shape in the 1800s, although some forms of death taxes can be traced back as far as the 1600s (Economist, 2007). Death taxes were, principally, introduced in the United States of America (USA) to fund wars. The American war with France was funded by the death tax collections of the 1700s, while their war with Spain was funded with the death tax revenues of the 1980s (NoDeathTax.Org, not dated). The international situation in modern times is moulded by issues surrounding recession, global warming, the need for extensive financial regulation, corruption and erosion of tax bases - not war. Taking the prevailing economic climate into account, death tax policies may not address all these issues appropriately.

Death taxes have once again become newsworthy due to the reintroduction of the federal estate tax into the USA's fiscal system. The taxation reforms brought about by President George Bush in 2001 (which included a reprieve in the federal estate tax) came to an end in 2010 (Donmoyer, 2010). The Obama administration did not continue with the reforms, thus resulting in the reintroduction of estate tax for all deaths occurring on or after 1 January 2011 (Donmoyer, 2010). This raised a furore in the USA, reigniting contentious debates as to whether estate tax (and more broadly - death taxes) should even form part of the fiscal system of the USA. Academics, including W Beach (director of the American Centre for Data Analysis), civil rights groups such as Tennesseans Against Death Taxes, Republicans and the American public in general are raising urgent calls for death tax reform - more specifically for the repeal of all forms of death taxes. The opponents of death taxes insist that death taxes should be repealed; however, the repeal cannot happen during a recession when so many states and nations are facing significant budget deficits (Coshocton Tribune, 2011:A9).

In its third interim report the Katz Commission of Inquiry into Taxation recommended further investigation into the capital transfer tax arising from deceased estates (taking into account international comparisons) in an attempt to achieve vertical equity in South Africa (Department of the National Treasury, not dated). In its fourth report - dealing with capital transfer tax - the Katz Commission considered the feasibility of including and/or expanding certain forms of capital transfer tax. The Katz Commission referred to the Report of the Margo Commission, which expressed the view that, although redistribution of wealth could be better achieved through the expenditure side of the budget, the actual and perceived redistributive effects of the tax system are nonetheless important, particularly in South Africa's circumstances (Department of the National Treasury, not dated). 
The Katz Commission pointed out that death tax contributes a minute percentage of the country's Gross Domestic Product, but it nevertheless recommended the retention of estate duty as a capital transfer tax (Department of the National Treasury, not dated). Twenty years have passed since the Katz Commission has made its recommendations in 1994 and South Africa still has estate duty in place, levied in terms of the Estate Duty Act (45/1955). In 2001 South Africa also introduced capital gains tax in terms of the Income Tax Act (58/1962).

In 2013 the Davis Tax Committee was formed with the purpose of evaluating the role of the South African tax system in the promotion of inclusive economic growth, employment creation, development and fiscal sustainability. The Committee takes into account in its work both domestic and global developments and, in particular, the long-term objectives of the National Development Plan (NDP) (Tax Review Committee, 2013).

The Davis Tax Committee has established a sub-committee on estate duty to evaluate the progressivity of South Africa's tax system and the role and continued relevance of estate duty to support a more equitable and progressive tax system. The sub-committee will also investigate the interaction between capital gains tax and estate duty (Tax Review Committee, 2013).

It is therefore evident that the debate around death taxes is still on-going and relevant and that a country's revenue authorities should consider the advantages and disadvantages of this type of tax as well as the possible alternatives available to them in achieving their goals and commitments.

\section{PURPOSE STATEMENT}

There is a real risk that the decision as to whether death taxes should be repealed or not may be a political one rather than one based on well-researched evidence. The decisions made in the USA regarding the abolition of death taxes could serve as a benchmark that other countries may consider. Changes in the economy and in society will require a change in the prevailing taxes (OECD, not dated), and looking back at what did not work in the past, will prevent the same mistakes from being made in the future.

The purpose of this study was to identify and investigate feasible alternatives for death taxes. Each alternative was considered in light of the manner in which it avoids or addresses the shortcomings of death taxes and the manner in which it addresses the concerns of the proponents and opponents of death taxes. The advantages and disadvantages of each proposed alternative were considered. In addition to identifying feasible alternatives, the study aimed to identify whether any of the identified alternatives could be suitable for South Africa.

\section{RESEARCH DESIGN AND METHODS}

In order to achieve the stated purpose a qualitative research study was performed. Merriam (1997:5) describes qualitative research as the cocoon from which multiple inquiry strategies may arise, all of which are aimed at assisting researchers in understanding a particular phenomenon. Two overlapping inquiry strategies were employed in performing the qualitative research - a literature review and a thematic analysis.

The primary benefit of a literature review for this study is that it provides insight into the debate in order to identify meaningful and pragmatic solutions to the problems that have sparked the 
death tax debate (Mouton, 2001:180). In the context of this study, the debate centres around which alternatives best address the shortcomings of death taxes and which alternatives could be a good fit for South Africa. The second (subsidiary) inquiry strategy is a thematic analysis. This is described as a 'method of identifying, analysing and reporting patterns (themes) within data' (Braun \& Clarke, 2006:79). The findings of this study are reported using a combination of the description of the patterns identified, the deductions made and conclusions reached thereon (Merriam, 1997:11).

\section{OVERVIEW OF THE DEATH TAX DEBATE}

The phrase 'death taxes' is a colloquial term used to describe taxes that are levied as a result of a person's death. The term includes, but is not limited to, taxes such as estate tax and inheritance tax (Economist, 2007). About.com (not dated) defines estate tax as the charge upon the right of deceased persons to transfer assets to their heirs after death. The definition is specifically extended to mention that the tax is based on the value of the estate and has no bearing on who inherits the estate. Inheritance tax is defined as the tax on the capital gain made by an heir on the inherited wealth (Dubay, 2010).

\subsection{Qualitative arguments against death taxes}

Political parties opposing the taxes declare them to be outright immoral (Kirchhoff, 2002). Others consider it socially despicable for the government to add insult to injury by demanding taxes when the family is grieving (Russell, 2008). Perhaps the most intriguing moral argument against death taxes is that they are 'communist taxes' (Independent Green Voice, not dated). The fundamental building block of capitalism is that individuals have the right to accumulate wealth for their own account. No redistributive model should be applied to capitalism, as redistributive theories are associated with communism and socialism (Independent Green Voice, not dated).

A further moral argument against death taxes is that they cause the dissolution of family businesses (Dubay, 2010). The death taxes target small (family-owned) businesses, which have high-value assets but whose assets are highly illiquid (Dubay, 2010). The only course of action for such businesses is to sell off assets in order to pay the taxes. This liquidation of assets leads to the eventual destruction of small businesses (Donmoyer, 2010).

Economists intimate that any tax should be judged by the degree to which it achieves fairness, the degree to which it is simple and how efficient it is (Joint Economic Committee United States Congress, 2006:25). In assessing whether death taxes achieve fairness, the Joint Economic Committee United States Congress (1998:30) introduced the concept of vertical and horizontal fairness. If taxpayers in progressively higher income brackets pay more tax than those in lower income brackets, then such a tax is said to achieve vertical fairness. Horizontal fairness is achieved when taxpayers in the same income brackets pay an equal amount of tax. The death taxes achieve neither vertical nor horizontal equity (i.e. the death taxes are not fair on all accounts). Wealthy taxpayers easily avoid such taxes (through the use of estate tax planners) and the burden then falls on the middle class (Joint Economic Committee Democrats, 2006:1) or those who were uninformed (Economist, 2007; Independent Green Voice, not dated). In freemarket systems it is unnecessary to implement taxes in order to prevent wealth accumulation (by a privileged minority) through inheritance; the ordinary functioning of the market achieves 
that goal (Mankiw, 2006). This free-market force was referred to in 1776 as 'The Invisible Hand' in Adam Smith's The Wealth of Nations, alluding to his view that opening the markets and allowing people freedom to trade for their own benefit would result in prosperity, with very little effort from a nation's government (Investopedia, not dated).

The most prominent argument spearheading the debate against death taxes is that of the hindrance of economic activity. Death taxes represent a tax on savings and capital investments (Dubay, 2010; Joint Economic Committee United States Congress, 2006:18). There is overwhelming agreement among economists that there should be no taxes on capital (Dubay, 2010). The first reason for this is that taxing capital discourages long-term savings (Economist, 2007) in favour of short-term consumption (Dubay, 2010; Joint Economic Committee United States Congress, 2003:i). Secondly, if capital is taxed (for example in the form of a death tax that would tax the amount of capital accumulated until the date of death) it could discourage entrepreneurship if a taxpayer seeks to increase spending instead of building capital. This could severely hamper job creation and job retention (Dubay, 2010; Russell, 2008), which are desperately needed for economic recovery.

Another argument against death taxes is that they cause double taxation - the assets now earmarked for tax (at the time of the death of the testator or at the time of disposal by the heirs) were acquired with the funds that remained after income and other taxes had been levied (Independent Green Voice, not dated).

According to Dubay (2010) the only beneficiaries of death taxes are estate tax advisers, credit life insurers and large businesses, with the state itself not receiving a substantial benefit.

\subsection{Qualitative arguments for death taxes}

In considering the fairness of death taxes, all the arguments centre around preventing wealth from being ingrained in one family line through inheritance ( $\varepsilon$ conomist, 2007). In other words, death taxes are intended to create income equality. Proponents of death taxes (which include billionaires Bill Gates and Warren Buffet) insist that death taxes preserve the meritocracy within society (Donmoyer, 2010). Graetz (2010) insists that the offspring of wealthy parents should not be allowed to inherit freely. Just as their parents incurred taxes in accumulating the wealth, so should the children incur taxes in inheriting that very same wealth.

Even though it is reported that the revenue collected from death taxes accounts for only $1 \%$ of the total fiscal revenue (Dubay, 2010) in the USA for example, that $1 \%$ covers $75 \%$ of Homeland Security costs (Graetz, 2010). The fiscus urgently needs the revenue generated by all taxes (including death taxes). Repealing any tax could result in an increase in other taxes or a decrease in service delivery by the state.

Another argument for death taxes is that they could increase donations to public benefit organisations if assets that form part of such donations are not subject to death taxes (Joint Committee on Taxation, 2008:6; Joint Economic Committee Democrats, 2003:1). This implies that a taxpayer could be more inclined to make testamentary bequests to public benefit organisations in the knowledge that such bequests would reduce the ultimate death tax liability.

\subsection{Quantitative arguments for and against death taxes}

Cagetti and De Nardi (2007) performed a quantitative study into the effects of death taxes on the economy. Their purpose was to quantify the impact of death taxes on aspects they identified 
as decisive to policymakers. These aspects were determined as business investment, estate transmission, wealth inequality and borrowing constraints. The research established that the elimination of death taxes would not result in an increase in accumulated wealth or capital (Cagetti \& De Nardi, 2007:40). This conclusion is pivotal to the death tax debate. The second critical conclusion reached by Cagetti and De Nardi (2007:40) is that the abolition of death taxes would not result in an increase in income or consumption disparities.

Cagetti and De Nardi (2007:40) acknowledge the fact that their mathematical model could not factor in the possible effects of death tax avoidance. Death tax avoidance has several permutations, which include aggressive estate planning, outright death tax evasion and manipulating the time of death in order to avoid death taxes. The latter avoidance measure is what Kopczuk and Slemrod (2001, not numbered) refer to as the elasticity of death. Death (more specifically, the date of death) is elastic in response to changes in a given death tax policy. The families of potential death taxpayers are willing to manipulate the date of death of their family members if that would result in a reduced death tax liability.

The glaring problem with the quantitative arguments for and against death taxes is that they are overly complex. More than twenty mathematical equations drove the critical conclusions reached in the abovementioned studies. Even though the studies may disprove or prove a particular argument in the debate, their findings will always remain questionable.

\section{PROPOSED ALTERNATIVES}

In identifying possible alternatives to death taxes for the current study a sample of countries that do not have death taxes was selected by the authors (summarised in TABLE 1). This study then sought to identify the taxes that have been implemented in those countries in lieu of death taxes. A country from each continent was selected. Certain countries included in the sample had some similarity to South Africa - whether political, social or economic. On the basis of these criteria the following countries were selected for the search for alternatives: Brazil, Russia, India, China, Australia, Mauritius, Canada, Hong Kong and Sweden.

The first four countries (Brazil, Russia India and China - BRIC countries) are politically and economically similar to South Africa. O'Neill (2001:S.03) described the BRIC countries as emerging-market economies that were set to rival the leading First World countries in the quest for global economic domination. South Africa was not initially identified as one of those emerging market economies but it was invited to join the BRIC countries in 2010 (Rowland, 2011). This led to the group of countries being referred to as the BRICS countries.

The primary purpose of including countries that are similar to South Africa in the sample was to increase the probability of identifying alternatives that would be suitable in a South African context. TABLE 1 depicts the taxes that are levied (on the incidence of death) by the countries in the sample. 
TABLE 1: Visual representation of alternative taxes

\begin{tabular}{|c|c|c|c|c|c|c|c|}
\hline & $\begin{array}{c}\text { Death taxes } \\
\text { (inheritance } \\
\text { tax or } \\
\text { estate } \\
\text { duty) }\end{array}$ & $\begin{array}{c}\text { Gift tax or } \\
\text { other } \\
\text { endowment } \\
\text { taxes }\end{array}$ & $\begin{array}{c}\text { Transfer } \\
\text { taxes }\end{array}$ & $\begin{array}{c}\text { Property } \\
\text { taxes }\end{array}$ & $\begin{array}{c}\text { Net } \\
\text { wealth } \\
\text { tax }\end{array}$ & $\begin{array}{l}\text { Capital } \\
\text { gains tax }\end{array}$ & $\begin{array}{c}\text { Income } \\
\text { tax }\end{array}$ \\
\hline \multicolumn{8}{|c|}{ Countries socio-economically or politically similar to South Africa } \\
\hline Brazil & $x$ & $x$ & $\checkmark$ & $x$ & $x$ & $\checkmark$ & $x$ \\
\hline Russia & $x$ & $x$ & $x$ & $x$ & $x$ & $x$ & $\checkmark$ \\
\hline India & $x$ & $\mathrm{Nl}$ & $\mathrm{Nl}$ & $\mathrm{Nl}$ & $\checkmark$ & $\mathrm{Nl}$ & $\mathrm{Nl}$ \\
\hline China & $x$ & $x$ & $\checkmark$ & $\checkmark$ & $x$ & $\checkmark$ & $\checkmark$ \\
\hline \multicolumn{8}{|l|}{ Australia } \\
\hline Australia & $x$ & $x$ & $x$ & $x$ & $x$ & $\checkmark$ & $\checkmark$ \\
\hline \multicolumn{8}{|l|}{ Africa } \\
\hline Mauritius & $x$ & $x$ & $x$ & $\checkmark$ & $x$ & $x$ & $x$ \\
\hline \multicolumn{8}{|c|}{ North America } \\
\hline Canada & $x$ & $\checkmark$ & $\checkmark$ & $x$ & $x$ & $\checkmark$ & $x$ \\
\hline \multicolumn{8}{|l|}{ Asia } \\
\hline Hong Kong & $x$ & $x$ & $x$ & $\checkmark$ & $x$ & $x$ & $x$ \\
\hline \multicolumn{8}{|c|}{ South America } \\
\hline $\begin{array}{l}\text { Brazil (as } \\
\text { above) }\end{array}$ & $x$ & $x$ & $\checkmark$ & $x$ & $x$ & $\checkmark$ & $x$ \\
\hline \multicolumn{8}{|l|}{ Europe } \\
\hline Sweden & $x$ & $x$ & $\checkmark$ & $\checkmark$ & $x$ & $\checkmark$ & $x$ \\
\hline
\end{tabular}

Source: Adapted from the International Estate and Inheritance Tax Guide 2012 and Tax Rates CC

$\mathrm{Nl}$ : denotes that insufficient information (from the abovementioned sources) was available to determine whether such taxes are levied at the incidence of death or not.

From the table above the alternative taxes implemented by these countries can be grouped as follows:

- Taxes that result in a deemed capital gain and taxes charged upon the transfer of that same property upon which the deemed capital gain arose (collectively referred to as 'deemed realisation alternatives'):

\section{o Transfer taxes}


O Capital gains tax

- Taxes that result in an increase in the tax liability of an individual (collectively referred to as 'income inclusion alternatives'):

0 Income tax

o Net wealth taxes.

The fact that countries that have no death taxes have implemented the abovementioned taxes is consistent with previous studies conducted on death tax alternatives. The studies did not focus on finding actual alternatives for death taxes, but rather on building frameworks within which alternatives could be found. One such study was conducted by the Joint Economic Committee on Taxation (2008: not numbered) and suggested that death tax should be formulated using either an income inclusion approach (framework) or a deemed realisation approach.

\subsection{Income inclusion alternatives}

Countries that have used this approach to identify and implement alternative taxes have either broadened the scope of the amounts that are subject to income tax or established new legislation to specifically deal with the taxation of 'wealth'.

\subsubsection{Income tax approach}

The income tax approach involves including amounts (bequests received) in gross income and subjecting these amounts to tax, similar to the taxation of items considered to be normal income, such as salaries and wages. The following countries have used income tax as the alternative to death taxes: Russia, Australia and China (see TABLE 1).

Russian income taxes are governed by Chapter 23 of the Tax Code of the Russian Federation Part Two No. 117-Fz of August 5, 2000. The Russian application of the income tax approach is to include the value of bequests in the income of the recipient of such bequests. However, the value of the same bequests is exempt from income tax because they represent amounts received through inheritance. Therefore bequests in Russia are, effectively, not subject to tax. There are no taxation consequences for the deceased.

Australia's income tax framework is governed by the Income Tax Act of 1986. In terms of Australian legislation, the deceased as a natural person does not receive an income tax deduction (in his or her final income tax calculation) for the value of income and assets bequeathed, even if they are bequeathed to charitable organisations. The deceased estate (as a separate person coming into existence after the death of the deceased) is taxed on all income and assets accrued after the date of death if there are no beneficiaries who are at present entitled to that income and those assets. Distributions made by the deceased estate are also not deductible in the hands of the deceased estate, even if those distributions are made to charitable organisations. The beneficiaries of the deceased are required to include the value of all assets and income received from the deceased and deceased estate, and all assets and income to which they are presently entitled, in their assessable income. Such income (aggregated with all other assessable income) is subject to tax using the progressive tax rates applicable to individuals (Australian Taxation Office, 2012b).

The income taxes of China are dealt with under China's Individual Income Tax (IIT) legislation. In accordance with the IIT of China, the recipients of real estate or land-use rights are required to include the value of such real estate and land-use rights in a special item of gross income called 
"other income". However, those same amounts then receive a full exemption from tax (Ernst \& Young, 2012:48).

Income tax is reputedly at the heart of addressing wealth inequality (Prasad, 2008:1) due to its progressive nature. Income tax vigorously endeavours to ensure that the liability for the tax falls on those who are best able to pay it. Another perceived advantage of income tax is that the tax base on which the tax is levied is 'neutral' (Dodge, 1978:1183). The tax base for an income tax consists of amounts earned by exercising one's intellect, whereas the tax base for consumption taxes consists of amounts consumed, and the tax base for wealth taxes consists of savings (whether transferred or not). Dodge (1978:1183) intimates that taxing consumption is extremely prejudicial (especially to the poor), as consumption is not an indication that one has wealth people who spend do not necessarily have a greater 'ability-to-pay' than those who save, as they may be spending borrowed money. Taxing wealth is also prejudicial, as this discourages future accumulation of such wealth (and hence restricts the future growth of the economy). Dodge (1978:1183) concludes that taxing income earned is the better measure (and a determinant of a person's 'ability-to-pay'), as all taxpayers are assumed to have the same ability to earn income.

Income tax also ensures timely revenue collection because it ensures that someone is taxed immediately - the fiscus does not have to wait for the income to be consumed, saved or transferred in order to collect its portion of the revenue. This attribute of income tax goes a long way to preventing the tax evasion which crippled death taxes (Dodge, 2003:591). Generally, income tax is a well-established tax in many countries. The advantage of using a wellestablished framework (which could be appropriately extended to serve the purposes of death taxes as well) is the ease of administration that flows from this (Dodge, 2003:591).

The first disadvantage of using the income tax approach is that taxing inherited wealth under the income tax framework results in a dilution of the tax base (Dodge, 1978:1189) and, consequently, in less revenue for the fiscus. This loss of revenue is explained as follows: with death tax the tax base is associated with one person (the deceased), and therefore that one person can be subject to a higher level of tax. However, with income tax, the tax base is associated with multiple taxpayers. The deceased and his beneficiaries may use this as a planning opportunity in order to ensure that the family unit as a whole pays the least tax possible.

A further disadvantage of the income tax approach is that the income on which the tax is determined is not all received in cash (but the liability for the tax requires cash settlement). Hence, inheritances such as properties received (and not sold) would thrust the taxpayer into a higher income tax bracket, but the taxpayer may not have the means to settle the tax due. Furthermore, people who earn low amounts of traditional income (e.g. wages and salaries) and receive large inheritances end up paying tax at higher rates, not only on the inheritances received, but also on their traditional income.

Income tax also suffers from practical disadvantages. A practical problem with including 'amounts' in income is the valuation of such 'amounts'. The valuation of any amount causes significant practical difficulties, mainly due to the complexities involved in valuing different types of 'amounts', including non-cash income streams and miscellaneous benefits. These complexities allow for the potential manipulation of the 'amounts' included in gross income (Dodge, 2003:588). 


\subsubsection{Net wealth taxes}

A net wealth tax is a tax levied on the net wealth owned by a person at the date of death (Gordon \& Rudnick, 1996:1-2). The net wealth tax should be clearly distinguished from a wealth transfer tax. A wealth transfer tax is a tax on the transfer of wealth from one person to another (Gordon \& Rudnick, 1996:1). The net wealth tax is regarded as an alternative developed using the income inclusion approach as, 'amounts' are included in an 'income' pool and are subject to tax using progressive tax tables or (more commonly) a flat rate.

India's net wealth tax is levied in terms of the Wealth-Tax Act of 1957 (the 'Wealth Tax Act'). The tax is charged on, inter alia, individuals, who are referred to as the 'assessees' in terms of that legislation. Section 2(m) of the Wealth-Tax Act (27/1957) defines 'net wealth' as the net result remaining when the assets owned by an assessee are reduced by any liabilities associated with those assets (for example, the value of a house less the associated mortgage bond). The assets specifically earmarked for tax (i.e. the tax base) include luxury items - those usually associated with wealth - such as yachts, cars and cash on hand (Venkatraghvan, 2012). The net wealth tax is levied over and above income tax and is calculated at a rate of $1 \%$ of the net wealth that exceeds 30 lakhs (this is equivalent to approximately 3 million Indian rupees) (0xford Dictionaries.com, not dated).

McKinnon (2012) argues that the net wealth tax has a considerably larger tax base than income tax, as the tax base of the net wealth tax not only comprises income but the assets that generate that income as well. This fact allows the fiscus to levy wealth taxes at low rates (such as that seen in India - where the net wealth tax is levied at 1\%) but still generate large amounts of revenue. Another advantage of the net wealth tax is that it has the ability to target not only newly created wealth but also wealth that has been built up and included in the archives for centuries. The net wealth tax also does not cause undue financial pressure on families. The tax is levied on excessively wealthy individuals (McKinnon, 2012).

A weakness of the net wealth tax is that it erodes wealth. If the assets owned by the assessee do not increase there would come a point where all the net assets of the assessee would be paid over to the fiscus as tax (as the tax is levied during the entire lifetime of a person and not merely on death). This may lead to stagnation in the economic growth of individuals, which in turn would lead to stagnation of the country's economy. The net wealth tax is not a form of double taxation, but rather a form of exponential taxation. Not only are the assets (constituting the wealth) acquired with income that was subject to income tax and consumption taxes, those very same assets are then subject to the net wealth tax in the following years of assessment in the hands of the same person. Furthermore, the administrative burden and costs associated with the implementation may exceed any perceived benefits of the net wealth tax.

\subsection{Deemed realisation alternatives}

This framework envisages the taxation of assets transferred from the deceased to the heirs, as if the assets had been sold (Joint Committee on Taxation, 2008:11).

\subsubsection{Transfer taxes}

BusinessDictionary. Com (not dated) defines a transfer tax (also referred to as a transfer duty) as any tax levied on the transfer of ownership from one person to another. Common transfer taxes include property transfer taxes, security transfer taxes and stamp duties. Transfer taxes 
are stand-alone taxes (i.e. separate from income tax) and are levied each time a transfer occurs. The taxes may be levied on either the transferee (in the case of the South African transfer duty) or on the transferor, being the deceased (as in the case of China's land appreciation tax). The following countries have used transfer taxes as alternatives for death taxes: Brazil, China, Canada and Sweden (see TABLE 1).

In Brazil, tax on any transaction may be levied at a federal, state or municipal level (PricewaterhouseCoopers, 2010:127). Two principal transfer taxes are levied on the transfer of property from the deceased to the recipients. Firstly, a 'State tax on causa mortis wealth transfer' is a tax levied on the transfer of property from the deceased to any recipients (Ernst and young, 2012:30). The tax is levied at an increasing rate (subject to a maximum rate of $8 \%$ ) on all property transferred by the deceased. The recipient of the property is liable for the tax (Ernst and Young, 2012:20). Secondly, a municipal tax is levied on the transfer of all real estate (land and immovable property) from the deceased to the recipients ( $E$ rnst and young, 2012:30). The rates at which the taxes are levied are between $0,5 \%$ and $6 \%$, depending on the municipality levying the tax. Again, the recipient of the property is liable for the tax (Deloitte, 2012a: not numbered).

In terms of the Chinese legislation a deed tax is levied on the value of property (consisting of real estate and land-use rights), gratuitously transferred to 'non-statutory successors' (Ernst and Young, 2012:49). The relatives of the deceased who are considered to be 'statutory successors' are the spouse, children, parents, grandparents and siblings of the deceased. The tax is levied at a rate of between $3 \%$ and $5 \%$ of the value of the property and the liability for the tax falls upon the recipient of the property (Deloitte, 2012b:17).

In Canada, real estate transfer taxes are levied only at a provincial level. Depending on which province levies the tax, the tax may be levied either in terms of the Property Transfer Tax Act or in terms of the Land Transfer Tax Act (Ernst and Young, 2012:37). There are several provinces that do not levy property transfer taxes, but in the provinces that do levy the tax, it is levied at a rate in the range of $0,5 \%$ to $2 \%$ of the market value of the property transferred. However, if the real estate is transferred to a family member, then the transaction will be exempt from tax. Both the property transfer tax and the land transfer tax are levied upon the acquirer of the property (Manitoba Finance, not dated).

Sweden levies stamp duty of $1,5 \%$ on the value of all real estate transferred (Deloitte, 2012c:14). The duty is also levied, at varying rates, on the transfer of other items such as shipstaxed at 0,4\% - and aircrafts - taxed at 1\% (Deloitte, 2012c:14).

According to Dodge (2004-2005:290) transfer taxes constitute a stable form of revenue for the fiscus as they generate revenue every time a transaction occurs. The fiscus does not have to wait until the end of the year of assessment in order to collect the revenue. Transfer taxes that are levied on the recipient of the property do not result in double taxation - the first tax that the recipient of the property would be paying in connection with that property would be the transfer tax.

Transfer taxes may result in income redistribution if they are correctly applied. A deemed realisation alternative can only be an effective wealth redistribution instrument if it is levied upon the transferee of assets (Dodge, 2004-2005:290). If a tax is levied upon the recipients of the deceased estate, then the deceased is incentivised to distribute his assets among multiple beneficiaries in order to decrease the tax liability in the hands of any one person. 
A disadvantage of transfer taxes is that the revenue generated from the transfer taxes is positively correlated to the economic conditions and thus revenue collections fluctuate as the economy fluctuates. This may result in decreased revenue collections during recessionary times - times when the fiscus most needs the revenue. The recessionary environment has resulted in a decrease not only in the volume of transactions, but also in the market value of property (Economist, 2007).

The Brazilian and Swedish interpretation of the transfer tax alternative may result in undue financial pressure being placed on families (Economist, 2007). The families become liable for tax on the deemed transfer of assets, and as such the family members may not have the cash to settle the tax and would have to sell the assets in order to raise the funds. The Chinese and Canadian interpretation of their transfer taxes do not result in the dissolution of undue concentrations of wealth (the deceased is not incentivised to distribute his wealth among multiple beneficiaries in order to reduce each beneficiary's tax liability) (Economist, 2007; Graetz, 2010). Moreover, the aforementioned interpretation of the transfer tax alternative does not actively contribute to preserving the meritocracy within a society. Family members who receive tax-free inheritances are likely to leave the labour force (Economist, 2007; Graetz, 2010) and live on wealth created by others as opposed to themselves.

\subsubsection{Capital gains tax}

A capital gain is defined as the positive difference between the proceeds from the sale of capital property and the base cost of that property (Canadian Revenue Agency, 2011a:21, Paragraph 3 (a) of the Eighth Schedule to the South African Income Tax Act (58/1962)). Capital gains tax is the tax levied on such a capital gain. For the purposes of the deceased, proceeds are defined as the market value of the assets at the date of death (Paragraph 40(1) of the Eighth Schedule to the South African Income Tax Act (58/1962)). The base cost of the asset is the purchase price paid by the acquirer and other expenses that are allowed to be added to the acquisition cost, such as conveyance fees (Australian Taxation Office, 2012:1; Canadian Revenue Agency, 201la:4; Paragraph 20(1) of the Eighth Schedule to the South African Income Tax Act $(58 / 1962))$. The following countries have used capital gains tax as the alternative to the death taxes: Brazil, China, Australia, Canada and Sweden (see TABLE 1).

Brazil does not have separate capital gains tax legislation (Deloitte, 2012a: not numbered), but capital gains are taxed as ordinary income at a flat rate of $15 \%$ as part of the income tax legislation.

In terms of Australian legislation, capital gains are taxed whenever there is a change in ownership of a property. The death of the deceased is a capital gains tax event that may result in a capital gain or loss for the deceased (Australian Taxation Office, 2012:1). However, if the assets on which the capital gains arise are transferred to the 'legal personal representative' or beneficiary of the deceased, then the capital gain is disregarded (Australian Taxation Office, 2012:1). A 'legal personal representative' of the deceased is the person who is responsible for the administration of the estate and is usually the executor of the estate (Australian Taxation Office, 2012:1).

The Canadian legislation deems the deceased to have disposed of all his property at market value at the date of death (Canadian Revenue Agency, 201lb:21). The capital gain is calculated as the difference between the market value of the asset at the date of death and its base cost. The gain is included in the income of the deceased and is subject to income tax. If the deceased 
bequeaths an asset to a charitable organisation, then the deceased may claim a deduction for the value of the assets so bequeathed (Canadian Revenue Agency, 2011b:16).

Sweden has separate capital gains tax legislation. Capital gains are taxed at a rate of $30 \%$ on the sale of, inter alia, property and shares (Ernst and Young, 2012:214). The recipient of the assets of the deceased estate is deemed to have acquired those assets at the same value as that at which the deceased acquired them ( $\varepsilon$ rnst and Young, 2012:15). The recipient of the assets of the deceased is not deemed to have any capital gain or income receipt on such assets, but merely acquires a base cost.

Taxpayers often disguise ordinary income as capital income in order to avoid taxation (Elliffe \& Huang, 2011). Capital gains tax ensures that even if taxpayers undertake such schemes they will still be subject to tax, albeit at a lower rate. Capital gains tax contributes towards establishing and preserving both horizontal and vertical fairness within a tax system (Elliffe \& Huang, 2011). Ellife and Huang (2011) argue that capital gains tax ensures that everyone is taxed according to their increase in wealth. They also state that the tax contributes to preserving the societal meritocracy by ensuring that the beneficiaries of the deceased do not freely inherit wealth that they did not work for, thereby keeping them in the active labour market. Capital gains tax increases the tax base on which the fiscus can generate revenue. It also supports the integrity of the income tax base by ensuring that an amount that escapes the income tax net is taxed in the capital gains taxation net ( $($ lliffe \& Huang, 2011)

A disadvantage of capital gains tax is that the determination of proceeds (market value of assets at the date of death) is extremely complex. Different valuation techniques may yield different proceeds and the valuations may be manipulated in order to suit the taxpayer (Fernandez, 2007:1). This has necessitated extremely complex legislation in order to tackle taxpayer schemes. Another disadvantage of capital gains tax is that it taxes unrealised gains; therefore the person who bears the liability for the tax may not have the cash to settle the tax liability (Dodge, 2004-2005:290).

As was previously mentioned, a deemed realisation alternative can only be an effective wealth redistribution instrument if it is levied upon the transferee of assets (Dodge, 2004-2005:290). Capital gains tax therefore does not encourage wealth redistribution, as the tax is upon the deceased (transferor of assets). Both capital gains tax and transfer taxes may be subject to manipulation - especially in jurisdictions where separate legal entities such as trusts are used.

\section{SUITABILITY OF PROPOSED ALTERNATIVES FOR SOUTH AFRICA}

Wealth redistribution is a critical concern for the South African government (Department of the National Treasury, 2013:3). This is reiterated by the fact that the National Treasury's priorities (for the next 10 years) include poverty alleviation and the correction of inequality through 'efficient public service delivery' (Department of the National Treasury, Not dated). This priority was further reinforced in the National Budget speech, where the Minister of Finance stated that the presidential objectives are, inter alia, 'to alleviate poverty and tackle inequality head on' (Department of the National Treasury, 2012:32).

Prasad (2008:vi) states that income and wealth inequality can be efficiently addressed through efficient service delivery, taxation and social transfers. The optimal mix of these ingredients will be country-specific. What should be noted from Prasad's study is that taxation is not the only 
redistributive tool that should be used in order to achieve equality - other redistributive tools should also be used.

\subsection{Suitability of income inclusion alternatives}

Any country would benefit if it were able to use its existing administrative structures in order to replace the death taxes (Dodge, 2003:559). In this regard, South Africa has a well-established income tax system (the income tax system has been in existence since 1962). The required changes to South Africa's income tax legislation in order to allow for the taxation of inheritances could be incorporated into the existing system, saving the South African fiscal authorities a significant amount of time and effort with regard to the implementation of a newly proposed policy.

According to Prasad (2008:1) income tax is at the heart of addressing wealth inequality due to its progressive nature and the fact that it vigorously endeavours to ensure that the liability for the tax falls on those who are best able to pay it. This view may indicate that subjecting inheritances to an income tax system may be an option for addressing some of the wealth inequalities in South Africa.

A net wealth tax will require additional effort and financial investment from the government, as South Africa does not currently have such legislation in place. A net wealth tax could generate substantial income for the government, as it has a considerably larger tax base than income tax (McKinnon, 2012). Because of this larger tax base the tax could be levied at a relatively low rate and cover both existing and newly created wealth (McKinnon, 2012). This option therefore also appears to have the potential of addressing income and wealth inequalities.

A hybrid approach (which leverages the strengths of both the net wealth tax and the income tax) may be a feasible solution for South Africa. Such a hybrid approach may necessitate the complete removal of capital gains taxation, as capital gains would be effectively taxed under the net wealth tax.

\subsection{Suitability of deemed realisation alternatives}

South Africa already applies both the deemed realisation alternatives identified above (transfer duty and capital gains tax). In terms of the definition of 'transaction' in section 1 of the Transfer Duty Act (40/1949), the transfer of property between the deceased and their heirs constitutes a taxable transaction. South Africa's capital gains tax legislation also provides that the deceased is deemed to have disposed of all their assets at market value, at the date of death, and is subject to taxation on the resulting gain. In terms of section $9(1)(e)(i)$ of the Transfer Duty Act $(40 / 1949)$ the heirs and legatees of the deceased are exempt from paying transfer duty.

Considering the fact that transfer taxes constitute a stable form of revenue for the government (Dodge, 2004-2005:290) because they generate revenue every time a transaction occurs, it could also present favourable alternative sources of revenue in South Africa.

As transfer tax and capital gains tax already exist within the South African fiscal system and since they have been implemented in a manner that is comparable to other countries (such as Australia and Canada), suggestions for South Africa to facilitate alternatives to death taxes could include amendments to the respective rates at which these taxes are levied. 
As indicated earlier taxes should be judged by the degree to which they achieve fairness (addressing social inequalities), simplicity and efficiency (Joint Economic Committee United States Congress, 2006:25). Taxes should also be measured by how they influence political incentives (Economist, 2007). Any suggested amendments to South Africa's tax system should therefore take these requirements into account.

\section{CONCLUSION}

The purpose of the study was to identify and investigate feasible alternatives for death taxes. This was achieved by considering alternative approaches adapted by a selection of countries and evaluating the advantages and disadvantages of each alternative. The countries that were considered do not levy death taxes but have incorporated these alternatives in their tax systems.

The advantages and disadvantages of the identified alternative taxes mean that these taxes compared as follows to the criteria established by the proponents and opponents of death taxes:

TABLE 2: Criteria as established by proponents and opponents of death taxes

\begin{tabular}{|c|c|c|c|c|}
\hline & Income tax & $\begin{array}{l}\text { Net wealth } \\
\text { tax }\end{array}$ & Transfer taxes & $\begin{array}{l}\text { Capital gains } \\
\text { tax }\end{array}$ \\
\hline \multicolumn{5}{|c|}{ Requirements of the proponents of death taxes } \\
\hline $\begin{array}{l}\text { Preservation of societal } \\
\text { meritocracy }\end{array}$ & 3 & 3 & 2 & 3 \\
\hline $\begin{array}{l}\text { Encouragement of charitable } \\
\text { giving }\end{array}$ & (1) & (1) & (1) & (1) \\
\hline Generation of revenue & 3 & 3 & 2 & 3 \\
\hline \multicolumn{5}{|c|}{ Requirements of the opponents of death taxes } \\
\hline $\begin{array}{l}\text { Does not hinder economic } \\
\text { activity }\end{array}$ & 2 & (1) & 2 & (1) \\
\hline Is not a form of double taxation & 3 & (1) & 2 & (1) \\
\hline $\begin{array}{l}\text { Simple legislation which provides } \\
\text { certainty for the taxpayer }\end{array}$ & 3 & 3 & 3 & (1) \\
\hline $\begin{array}{l}\text { Does not cause undue financial } \\
\text { pressure on families }\end{array}$ & (1) & 3 & 2 & (1) \\
\hline
\end{tabular}

Source: Compiled by the authors

3: This tax addresses the issue raised by either the proponents or opponents of death taxes in a manner that would be satisfactory to the relevant party.

(1) This tax addresses the issue raised by either the proponents or opponents of death taxes in a manner that would not be satisfactory to the relevant party.

2 : This tax does not address the issue raised by either the proponents or opponents of death taxes. 
Any alternative tax will involve a balancing act between the efficiency of the tax, the manner in which the tax achieves equity within a society and other factors that are important to that country (Joint Economic Committee on Taxation, 2008:3).

Several permutations and uniquely South African interpretations of the identified alternative taxes may be considered as viable alternatives. In the search for alternatives it should be noted that there are no incorrect answers. Alternatives considered for South Africa should aim to achieve a balance between efficiency, social equity and other policy objectives. The Joint Economic Committee on Taxation (2008:3) states that, 'The choice of one ... system over another necessarily will involve trade-offs among efficiency, equity, administrability, and other factors ...' It is submitted that it is this trade-off that will be unique for each country and that it is a balance that will need to be subject to constant re-evaluation.

As South Africa has already implemented two alternatives for death taxes but has not abolished its own death tax, it is clear that further research is required into the exact mix of alternative taxes that will be optimal for the country, taking into account the identified advantages and disadvantages.

\section{SUGGESTIONS FOR FURTHER RESEARCH}

The study has established that there are various advantages and disadvantages attached to the identified alternatives for death taxes that need to be evaluated and applied to South Africa's unique circumstances. Extensive further research is required to arrive at the optimal tax system for South Africa.

Research should be undertaken into the best measure of a taxpayer's 'ability-to-pay' taxes as this may lead to better frameworks for establishing alternatives for death taxes.

Further research is also required into South Africa's application of the revenue raised from its death tax (estate duty). As part of its fiscal arsenal, South Africa has implemented various forms of transfer taxes, the capital gains tax and a death tax, while the countries studied do not have death taxes and have either transfer taxes or capital gains tax. The research should investigate whether the revenue collected from death taxes is being applied efficiently and effectively.

Even though it seems that countries have not sought to use consumption taxes (such as sales tax or value added tax) as death tax alternatives (based on the alternative taxes implemented by the countries identified in the study), the consumption tax alternative may be worth considering.

\section{LIST OF REFERENCES}

About.com. (n.d.). Death Tax. [Online] Available from: http://wills.about.com/od/termsbeginningwithi/g/inheritancetax.htm. [Accessed 2012-03-23].

Australian Taxation Office. (2012a). Deceased estate and capital gains tax. [Online] Available from http://www.ato.gov.au/content/37184.htm [Accessed 2012-09-20]. 
Australian Taxation Office. (2012b). Managing the tax affairs of someone who has died. [Online] Available from http://www.ato.gov.au/individuals/content.aspx?doc $=/$ content $/ 31669 . \mathrm{htm} \& \mathrm{pc}=001 / 002 / 060 / 005 / 001 \& \mathrm{mnu}=0 \& \mathrm{mfp}=$ \&st $=$ \&cy $=$ [Accessed 2012-07-28].

Baucus, M. (2008). Estate tax alternatives. FDCH Congressional Testimony, 2008-12-03. [0nline] Available from: EBSCOhost: MasterFILE Premier: http://0search.ebscohost.com.innopac.up.ac.za/login.aspx?direct=true\&db=f5h\&AN=32y2886591513\&site=e host-live\&scope =site [Accessed 2012-02-11].

Braun, V., \& Clarke, V. (2006). Using thematic analysis in psychology. Qualitative Research in Psychology, 3(232):77-101.

Business Dictionary.Com. Transfer tax. (n.d.). [Online] Available from http://www.businessdictionary.com/definition/transfer-tax.html [Accessed 2012-10-01].

Cagetti, M \& De Nardi, M. (2007). Estate Taxation, Entrepreneurship, and Wealth. [Online] Available from http://www.nber.org/papers/w13160.pdf [Accessed 2012-02-05].

Canadian Revenue Agency. (2011a). Capita/ Gains. [Online] Available from http://www.craarc.gc.ca/E/pub/tg/t4037/t4037-1le.pdf [Accessed 2012-09-09].

Canadian Revenue Agency. (2011b). Preparing Returns for Deceased Persons. [Online] Available from http://www.cra-arc.gc.ca/E/pub/tg/t4011/t4011-1le.pdf [Accessed 2012-09-16].

Coshocton Tribune. (2011). Find alternative funding before ending estate tax. Coshocton Tribune, 23 June:A.9. [Online] Available from: Proquest: ProQuest Entrepreneurship: http://search.proquest.com/docview/846917991? accountid=14717 [Accessed: 2012-02-10].

Deloitte (2012a). International Tax Brazil Highlights (2012). [Online] Available from http://www.deloitte.com/assets/Dcom-Global/Local\%20Assets/Documents/Tax/ Taxation\%20and\%20Investment\%20Guides/2012/dttl_tax_highlight_2012_Brazil.pdf [Accessed 2012-09-16]

Deloitte (2012b). Taxation and Investment in China (2012). [Online] Available from http://www.deloitte.com/assets/Dcom-Global/Local\%20Assets/Documents/Tax /Taxation\%20and\%20Investment\%20Guides/2012/dttl_tax_guide_2012_China.pdf [Accessed 201209-30].

Deloitte (2012c). Taxation and Investment in Sweden (2012). [Online] Available from http://www.deloitte.com/assets/Dcom-Global/Local\%20Assets/Documents/Tax /Taxation\%20and\%20Investment\%20Guides/2012/dttI_tax_guide_2012_Sweden.pdf [Accessed 2012-10-06].

Department of the National Treasury (2012). National Budget Speech. [Online] Available from http://www.treasury.gov.za/documents/national\%20budget/2012/speech/speech.pdf [Accessed 2012-10-06].

Department of the National Treasury (2013). National Budget Speech. [Online] Available at http://www.treasury.gov.za/documents/national\%20budget/2013/review/FullReview.pdf

Department of the National Treasury (n.d.). Fourth Interim Report Of The Katz Commission Of Inquiry Into Taxation. [Online] Available from http://www.treasury.gov.za/publications/other/katz/4.pdf [Accessed 2014-06-25].

Department of the National Treasury (n.d.). The Role of the National Treasury. [Online] Available from http://www.treasury.gov.za/nt/info.aspx [Accessed 2012-10-06]. 
Dodge, J. (1978). Beyond Estate and Gift Tax Reform: Including Gifts and Bequests in Income. Harvard Law Review. 91:1177-1211 [Online] Available from http://www.jstor.org/stable/1340475 [Accessed 2012-08-02].

Dodge, J. (2003). Comparing a reformed estate tax with an accessions tax and an income-inclusion system, and abandoning the generation skipping tax [Online] Available from http://0heinonline.org.innopac.up.ac.za/HOL/Page? public=false\& handle=hein.journals/smulr56\&men_hide $=$ false\&men_tab $=$ citnav\&collection $=$ journals\&page $=551[\mathrm{Ac}$ cessed 2012-08-02].

Dodge, J. (2004-2005). Alternatives to the current federal wealth tax transfer system. Tax Law Journal., 58:270-312 [Online] Available from http://0-

heinonline.org.innopac.up.ac.za/HOL/Page?public=false\&handle=hein.journals/tx/r58\&men_hide $=f a$ Ise\&men_tab =citnav\&collection=journals\&page=279 [Accessed 2012-08-02].

Donmoyer, R. (2010). Return of Estate Tax Looms as Final Impediment to Extending Bush Tax Cuts. [Online] Available from: http://www.bloomberg.com/news/2010-11-29/return-of-estate-taxlooms-as-final-impediment-to-extending-bush-tax-cuts.html [Accessed 2010-01-19].

Dubay, C. (2010). The Economic Case Against the Death Tax. [Online] Available from:

http://www.heritage.org/research/reports/2010/07/the-economic-case-against-the-death-tax [Accessed 2012-01-17].

Economist. (2007). The case for death duties. Economist, 385(8552):90 (1p). [Online] Available from: EBSCOhost: Business Source Premier: http://0-

search.ebscohost.com.innopac.up.ac.za/login.aspx?direct=true\&db=buh\&AN=27238803\&site=ehost live\&scope=site [Accessed: 2012-01-16].

Elliffe, C. \& Huang, CC. (2011). Hard to argue with benefits of capital gains tax. [Online] Available from http://www.nzherald.co.nz/business/news/article.cfm?c_id= 3\&objectid $=10698913$ [Accessed 2012-09-22].

Ernst and Young. (2012). International Estate and Inheritance Tax Guide (2012). [0nline] Available from http://www.ey.com/Publication/vwLUAssets/2012-international-estate-and-inheritance-taxguide/\$FILE/2012-international-estate-and-inheritance-tax-guide.pdf [Accessed 2012-06-05].

Fernandez, P. (2007). Company valuation methods. The most common errors in valuations. [0nline] Available from http://www.iese.edu/research/pdfs/DI-0449-E.pdf [Accessed 2012-10-06].

Gordon, R \& Rudnick, R. (1996). Taxation of Wealth. [Online] Available from http://www.imf.org/external/pubs/nft/1998/tlaw/eng/ch10.pdf [Accessed 2012-07-21].

Graetz, M. (2010). It's fair and we need the revenue. [0nline] Available from: http://online.wsj.com/article/SB10001424052748704358904575477593075638722.html [Accessed 2012-04-09].

Independent Green Voice (n.d.). Abolish the death tax. [Online] Available from: http://www.sovereignty.org.uk/features/articles/manifesto07/iht.html [Accessed 2012-02-07].

India. Wealth-Tax Act. (1957). [Online] Available from http://law.incometaxindia.gov.in/ DIT/other-income-tax-acts.aspx?page=0DTA\&Tabld=tab_WTA [Accessed 2012-10-01].

Investopedia (n.d.). Adam Smith and "The Wealth Of Nations". [Online] Available from: http://www.investopedia.com/articles/economics/09/adam-smith-wealth-of-nations.asp [Accessed 2014-06-30]. 
Joint Committee on Taxation. (2008). Description and analysis of alternative wealth transfer systems. [Online] Available from http://www.jct.gov/publications.html?

func $=$ startdown\&id $=1318$ [Accessed 2012-02-11].

Joint Economic Committee Democrats. (2003). Revisiting myths about the estate tax: rhetoric versus reality fact sheet. [Online] Available from:

http://jec.senate.gov/archive/Documents/Reports/estatetaxfact18june2003.pdf [Accessed 201202-04].

Joint Economic Committee Democrats. (2006). Who will pay for repealing the estate tax?. [Online] Available from: http://jec.senate.gov/archive/Documents/Reports/whowillpayestatetax2006.pdf [Accessed: 2012-02-04]

Joint Economic Committee United States Congress. (1998). The economics of the estate tax. [Online] Available from: 1. http://www.house.gov/jec/fiscal/tx-grwth/estattax/estattax.pdf [Accessed 2012-01-17].

Joint Economic Committee United States Congress. (2003). The economics of the estate tax: an update. [Online] Available from: http://papers.ssrn.com/sol3/papers.cfm?abstract_id $=678842$ [Accessed 2012-02-04].

Joint Economic Committee United States Congress. (2006). Costs and Consequences of the Federal Estate Tax. [Online] Available from:

http://jec.senate.gov/republicans/public/index.cfm?p=Studies\&ContentRecord_id=B28B507AE016-4B4A-9054-6F7C2B7A9515 [Accessed 2012-02-04].

Kirchhoff, S. (2002). Senate Fails to Repeal Federal Estate Tax. Business and Economics. [Online] Available from: Proquest: ABI/INFORM Complete:

http://search.proquest.com/docview/464313655?accountid=14717 [Accessed 2012-02-10]

Kopczuk, W \& Slemrod, J. (2001). Dying to save taxes: Evidence from estate tax returns on the death elasticity. [Online] Available from http://www.nber.org/papers/w8158.pdf?new_window=1

[Accessed 2012-04-29].

Manitoba Finance (n.d.). Land Transfer Tax. [Online] Available from http://www.gov.mb.ca/finance/landtransfertax.html [Accessed 2012-10-01].

Mankiw, G. (2006). The estate tax debate. [Online] Available from http://gregmankiw.blogspot.com/2006/06/estate-tax-debate.html [Accessed 2012-04-07].

McKinnon, R. (2012). The Conservative Case for a Wealth Tax [Online] Available from http://online.wsj.com/article/SB10001424052970203462304577139232881346686.html [Accessed 2012-10-01].

Merriam, B. (1998). Qualitative research and case study applications in education. San Francisco: Jossey-Bass Publishers.

Mouton, J. (2001). How to succeed in your Master's \& Doctoral studies. Pretoria: Van Schaik Publishers.

NoDeathTax.Org (n.d.). Brief History of the Death Tax. [Online] Available from http://www.nodeathtax.org/deathtax/history [Accessed 2012-06-16].

O'Neill, J. (2001). Building Better Global Economic BR/Cs. [Online] Available from http://www.goldmansachs.com/our-thinking/topics/brics/brics-reports-pdfs/build-betterbrics.pdf [Accessed 2012-07-14]. 
OECD (n.d.). Tax Policy Development in Denmark, Italy, the Slovak Republic and Turkey. [Online] Available from: http://www.oecd.org/document/32/0,3343, en_33873108_33873309_37154720_1_1_l_1,00.html [Accessed 2012-02-17].

Oxford Dictionaries.com (n.d.). Definition of Lakh in Eng/ish. [Online]. Available at http://www.oxforddictionaries.com/definition/english/lakh [Accessed 2014-06-29].

Prasad, N. (2008). Policies for redistribution: The use of taxes and social transfers. [Online] Available from

http://www.ilo.org/public/english/bureau/inst/publications/discussion/dp19408.pdf [Accessed 2012-10-13].

PricewatershouseCoopers (2010). Doing Business and Investing in Brazil. [Online] Available from http://www.pwc.com.br/pt/publicacoes/assets/doing-business-10.pdf [Accessed 2012-09-16].

Rowland, R. (2011). BRIC Countries Invite South Africa to Join. [Online] Available from http://www.moneyandmarkets.com/bric-countries-invite-south-africa-to-join-42196 [Accessed 2012-07-14].

Russell, R. (2008). Calls increase for estate tax repeal. [Online] Available from:

http://www.accountingtoday.com/ato_issues/2008_1/26297-1.html?zkPrintable=true [Accessed 2012-02-11].

Russia (n.d.). Tax Code of the Russian Federation Part Two no. 117-FZ of 2000 [Online] Available from http://www.russian-tax-code.com/Partl [Accessed 2012-10-01].

South Africa. (2012). Transfer Duty Act, No. 40 of 1949. Government Gazette, 565(35491):1-385. [Online] Available from http://www.info.gov.za/view/DownloadFileAction?id=169974 [Accessed 2012-10-06].

South Africa. Estate Duty Act, No. 45 of 1955. In: SAICA. 2009/(2010). SAICA Legislation Handbook 2009/(2010). Durban: LexisNexis.

South Africa. Income Tax Act, No. 58 of 1962. In: SAICA. 2009/(2010). SAICA Legislation Handbook 2009/(2010). Durban: LexisNexis.

Tax Review Committee. (2013). The Davis Tax Committee. [Online] Available from http://www.taxcom.org.za/ [Accessed 2014-06-25].

Venkatraghvan, D. (2012). Multiple assets in India? Don't forget wealth tax. [Online] Available from http://articles.timesofindia.indiatimes.com/2012-01-17/other-news/30635161_1_net-wealthwealth-tax-act-assets [Accessed 2012-10-01]. 